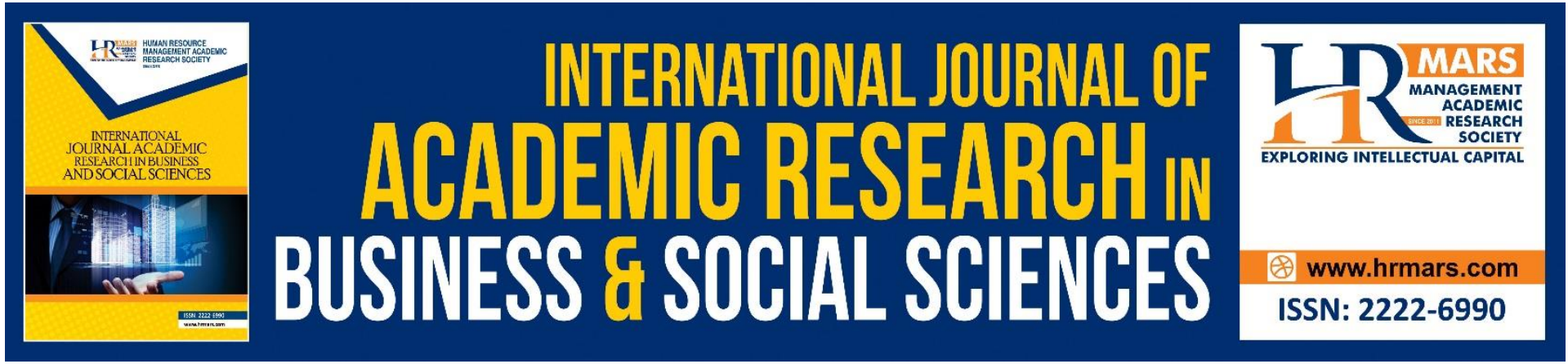

\title{
Financial Management of Family Institutions in Iqbal Membina Jaya Children's Novel
}

\section{Mohd Shukrey Ahmad, Kamariah Kamarudin, Nadiatul Shakinah Abdul} Rahman

To Link this Article: http://dx.doi.org/10.6007/IJARBSS/v11-i7/10597

DOI:10.6007/IJARBSS/v11-i7/10597

Received: 28 May 2021, Revised: 30 June 2021, Accepted: 18 July 2021

Published Online: 29 July 2021

In-Text Citation: (Ahmad et al., 2021)

To Cite this Article: Ahmad, M. S., Kamarudin, K., \& Rahman, N. S. A. (2021). Financial Management of Family Institutions in Iqbal Membina Jaya Children's Novel. International Journal of Academic Research in Business and Social Sciences, 11(7), 1394-1411.

\section{Copyright: @ 2021 The Author(s)}

Published by Human Resource Management Academic Research Society (www.hrmars.com)

This article is published under the Creative Commons Attribution (CC BY 4.0) license. Anyone may reproduce, distribute, translate and create derivative works of this article (for both commercial and non-commercial purposes), subject to full attribution to the original publication and authors. The full terms of this license may be seen at: http://creativecommons.org/licences/by/4.0/legalcode

Vol. 11, No. 7, 2021, Pg. 1395 - 1411

Full Terms \& Conditions of access and use can be found at http://hrmars.com/index.php/pages/detail/publication-ethics 


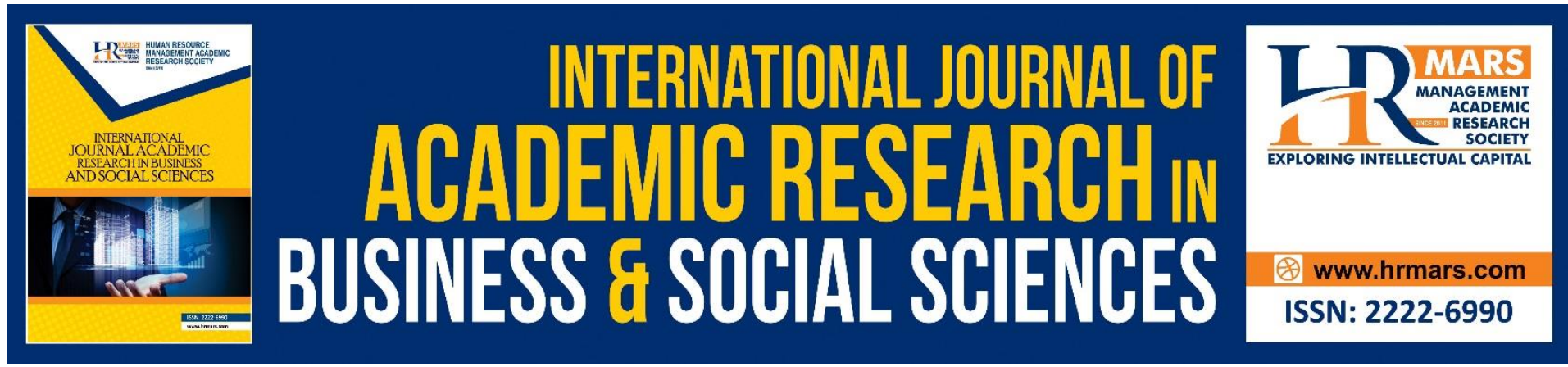

\title{
Financial Management of Family Institutions in Iqbal Membina Jaya Children's Novel
}

\author{
Mohd Shukrey Ahmad \\ Faculty Modern Language and Communication, Universiti Putra Malaysia, Serdang, Selangor, \\ Malaysia \\ Kamariah Kamarudin \\ Faculty Modern Language and Communication, Universiti Putra Malaysia, Serdang, Selangor, \\ Malaysia \\ Nadiatul Shakinah Abdul Rahman \\ School of Language, Civilisation and Philoshopy, Universiti Utara Malaysia, Sintok, Kedah, \\ Malaysia
}

\begin{abstract}
This study was conducted to examine the elements of financial management found in novel lqbal Membina Jaya written by Radzemah Bolhassan. Financial management is an important factor in a family institution. This is because financial management can impact everyday activities and lifestyles. Therefore, this financial management should be understood by each family member including children so that they are aware of the financial situation that his family has. In the context of literary works, the implementation of this financial management knowledge should be implemented so that readers especially children will be educated and knowing what steps need to be done to control the financial situation of the family. Thus, the novel lqbal Membina Jaya will be analysed using the approach nodded by Deacon and Firebaugh on financial management involving aspects of Input, Throughput, and the third one, Output. While each of these aspects will be detailed with several sub-topics, namely the input aspect containing aspirations and goals, economic risk (events), movements (trends), and income patterns. The throughput aspect involves planning and implementation as well as output aspects encompassing the achievement of expected goals and effective use of resources. In this regard, the lqbal Membina Jaya indeed has aspects of financial management within the family and can provide knowledge to readers to be wise in managing the family economy.
\end{abstract}

Keywords: Childre, children's Literature, Finance, Family, Novels

\section{Introduction}

Financial management is a matter for every level of society to pay attention to. This is because the aspect of financial management can influence all activities of daily living both 
individuals, families, communities and countries. According to Rahman and Zulkifly (2016: 86) money plays an important role in facilitating economic transactions and meeting the needs of the community today. Ineffective financial management will result in a financial crisis. Without enough money it is very difficult to meet the desired needs and services. This is clearly understood that without a stable financial position in family institutions will cause all activities and needs to be disrupted. Therefore, in every head of the family in a family institution it is necessary to understand financial management well in order to ensure the economic stability of the family and emotions of the children in particular.

If, financial management is not properly managed will have a huge impact on themselves. This situation occurs when parents experience a financial crisis so it cannot provide the best for the children especially involving education and the future of the children. Moreover, children who are growing up and increasing age also often ask to meet desires and demands. However, when parents experience a financial crisis, this situation will further delay the desire and demands of the children. When this condition occurs, the emotions of the children will be disrupted so that they begin to rebel. This is as pointed out by Rahman, Muhammad \& Sujud (2019) which states that if this emotional disorder is not well controlled will cause the situation to become more complicated, chronic and severe. At the same time, the emotions of parents were also disturbed by their children's redress and demands.

Furthermore, this situation will indirectly encourage parents to find easy ways in earning money such as borrowing from loan shark or engaging in illegal activities such as gambling or selling drugs. The same goes for the children who are feared to take an easy way to earn money to fulfil their desires. For example, they can get stuck and engage with activities that can damage their morals and deeds such as stealing, blackmailing and bullying. According to the (http://www.myhealth.gov.my/) children and teenagers steal for wanting to have items equivalent to classmates but, cannot afford to buy them so cause they steal. This very clearly shows that the economic instability of families and weaknesses in financial management will prompt kids to take an easy way to get the desired item. Parents who cannot afford to fulfil the wishes of children will be inclined to actions beyond control in order to seek satisfaction themselves.

This is as pointed out by Sabri and Ramli (2018: 1) that financial education should start at home and children should be exposed to financial aspects as early as their age as the saying states "if you want to bending bamboo let from the ribs. Similarly, the financial aspects of children require parents to teach their children about the importance of financial education. This clearly shows that children's financial education should also be taught and was a minor consciousness so that they can understand well when they are already reaching adulthood.

Therefore, for every family institution, especially family leaders, plays an important role in ensuring that family finances can be managed and planned properly in order to ensure the economic and financial stability of the family. This is because family financial management will influence a family's lifestyle to meet the needs, needs and comfort of life. According to Othman (2002: 102), financial management is an orderly way to control and plan expenses to achieve life goals and needs. Among the benefits that can be derived from managing finance is to enable a person to achieve the goals set, ensure that financial resources are adopted properly, increasing self-discipline in planning and using finances, providing opportunities to value money gained, create awareness on long-term planning and shortterm goals, responsible for current and future lives, helping to meet financial challenges more efficiently and enhancing knowledge in financial aspects. 
Ahmad and Omar (1988: 30) also argue that management is needed when there are problems that need to be solved, there is a desire that each has its own value, there is a need to be achieved, and there is something that needs to be changed. In addition, there are several factors that influence management, namely the value, condition or atmosphere and mental and physical abilities of a person. In managing finances, failure will also trigger various problems to families and communities. If the weaknesses in financial management are not addressed properly then there will be problems such as the collapse of household institutions, crime, hostility and so on which in turn disrupt the peace of society and the country. According to Samah (2017) there is a study stating that more than 20 percent of Muslim couples who experience financial problems within the age of five years of marriage will lead to early age divorce, especially among young couples.

Facing the financial crisis in family life coupled with the economic downturn has become a challenge that many couples have to face. He added that every couple needs to have a strong financial plan as a supply to face the future because there will be difficulties to realize dreams when faced with a financial crisis. Moreover, Othman (2002: 5), also argues that failure in financial management can usually lead to life frustration, self-conflict, and in turn affect the quality of life. This matter should be taken seriously so that it can be dealt with effectively and can prevent the occurrence of undesirable situations to household institutions.

According to Halim (2014) financial planning is very closely related to the rotation of a person's life starting from the early stages of life that is childhood and adolescence as well as during career to ensure financial integrity in the family. Therefore, the financial management of this family should be used as education in society and should also be taught to children. The use of reading materials is the best step to educate children to understand and learn aspects of financial management in the family. Therefore, literary material such as this novel is seen as appropriate to apply the elements of financial management because it is known that the novel can have a deep appreciation effect to its readers. According to Farlin (2019), the importance of financial knowledge from an early age should not be taken lightly, instead it should be applied as early as preschool age again so that children grow up to be money-savvy individuals, thus being able to manage their own lives well. It is also stated that financial education should be given as early as the age of four years so that they have started saving and managing money wisely and can form lifelong saving habits. It can be said that this financial management education needs to be learned by children so that they can manage finances as well as possible and be able to build ambitions in the future.

Therefore, this paper will focus on the financial management of family institutions such as Input, Throughput, and, Output as presented by Deacon and Firebaugh using Iqbal Membina Jaya children's novel by Radzemah Bolhassan as a research data.

\section{Literature Review}

Based on research on past studies shows a variety of studies on financial management. In this section, the discussion will be seen through two categories, namely financial management involving individuals and organizations.

\section{Individual Financial Management}

Financial management study involving children as touched by Sabri et. al. (2017) focuses on interactive workshops on money and money management through money-wise programs or Smart Money. This program targets the level two primary school children from grade four to grade six aged 10 to 12 years. This program aims to expose children to the knowledge and 
skills in managing personal finances with the guidance of parents and adults. The program exposes children's financial management through toys such as conservative board games aimed at sharpening children's soft skills in communication, strategic planning, and critical thinking. They also explained that these games could help children in managing finances and applying them in children's lives. Therefore, parents, guardians, and teachers play an important role in helping children to be able to manage their finances prudently. In this regard, parents, guardians, and teachers need to use innovative and creative techniques and approaches in educating children about money and financial management.

In addition to financial management studies on children, previous studies have also examined financial management in student groups. For example, Rahman and Zulkifly (2016) highlighted a study on the determining factors of financial management for Universiti Kebangsaan Malaysia (UKM) students. This study was conducted on 200 respondents involving 100 undergraduate students and 100 postgraduate students. Based on the study has proven that financial literacy factors play an important role in good financial management practices for both groups of students. However, aspects of funding sources and expenditure management only affect the financial management practices of postgraduate students. They also suggested that courses related to financial management should be offered at all levels of study so that students can apply financial literacy in financial management practices.

According Norazam and Othman (2017) also expressed views on the relationship between the quality of financial management education and the level of financial literacy. The study was conducted on 30 college and university students around Bangi Selangor. The study used the SERVQUAL Model and instruments to determine the level of student literacy. The results of the study show that students' satisfaction with the courses offered in colleges and universities is high. This proves that the quality of financial management education is good and shows a high minimum value. The level of financial literacy of the respondents is also at a high level. Thus, financial management is an important thing in life. Researchers also recommend that colleges and universities enrich the quality of financial management education so that youths are more financially literate.

Azmi et. al (2018) shows the similarities of the study with Rahman and Zulkifly (2016) as well as Norazam and Othman (2017) from the point of view of financial management discussions on students. The study focuses on the influence of financial knowledge and spending patterns on student financial management practices. The study was conducted on students of Kolej Universiti Islam Melaka (KUIM) involving 120 students. Based on the study shows that the level of student financial management practices is at a moderate level while the level of student spending pattern is at a high level. The results also show that there is a positive relationship between financial knowledge and financial management practices. This means that financial knowledge factors and spending patterns will influence student financial management practices

Besides, the study of Bakar et. al (2019) shows similarities in terms of the discussion of issues related to financial management. This study shows that female respondents, especially students in the Faculty of Economics and Management (FEP), Universiti Kebangsaan Malaysia (UKM), lack skills and are more vulnerable to unwise financial management. Based on the results of the study shows that the respondents who have financial problems are mostly from low-income families, namely from the B40 group. Based on funding sources, the majority are PTPTN borrowers. Most respondents also agree that they feel frustrated, depressed, and depressed when they cannot help families who need money, face financial problems and do not wisely manage personal expenses. Financial problems also cause them to limit their daily 
food intake. The government and non-government need to strengthen the offer of education financing, especially students from low-income families B40. Therefore, financial management courses should be included in the curriculum at all levels of education so that children understand the challenges of financial management.

The study of financial management on students shows continuous continuity. This is as shown through the study of Ramli et. al (2020). The study focuses on a comparative study between Malaysian and Indonesian students on the financial management strategies of married students. They explain that proper financial management strategies can help married students deal with serious financial problems. The study was conducted on 50 students of SMEs and 50 students of Universitas Bina Darma Indonesia (UBDI) aged between 18 to 25 years. The results of the study are based on four elements, namely the determination of information, budget, savings and financial records. Overall, the level of financial management strategy of UKM respondents is higher than the level of financial management strategy of UBDI respondents. However, both respondents from UKM and UBDI are at the same level, which is a moderate level of financial management strategy practice.

In addition, research on previous studies found that financial management is also show through an adult's perspective. According to a study by Abdullah et. al. (2018) overall young employee respondents were found to be less knowledgeable in some aspects of financial management especially those related to credit, takaful, and Islamic banking. Financial management practices are an important component in debt management because if financial management is practiced wisely and prudently can avoid facing financial problems and thus increase investment savings. Besides, good financial management practices can encourage individuals to train themselves to manage their debt burden better. However, financial problems that are not curbed and not managed wisely will lead to a high debt burden. The results of the study show that financial literacy related to credit cards, credit card charges, and loan repayment periods need to be fully controlled by young employees. The government also plays an important role in fostering awareness of debt management. Exposure to finance should be given to young people who have just entered the world of employment and financial education from the grassroots is very much needed.

\section{Organizational Financial Management}

Financial management studies not only involve individuals because financial management also involves an organization. According to Husaina Banu Kenayathulla (2015) financial management of a school organization is a process of optimizing the use of money so that this organization can achieve the set educational objectives. This study involved a respondent who is a headmaster for a Tamil national type school in Kuala Kangsar, Perak. Based on the researcher's observations on the respondents showed that the respondents have managed school finances effectively including managing allocations according to financial management guidelines, preparing expenditure estimates for future foreclosure, returning excessive allocations, performing and completing all necessary preparations to audit school accounts regularly, and neatly.

Besides, Arus et. al (2018) also provide a similar view to Kenayathulla (2015) on the role of headmasters as the main leadership of the school responsible for ensuring that every source of income and finances of the school is well manage. Based on the study, it has been proven that school leaders, namely principals, have practiced financial management procedures and procedures correctly and accurately. This shows that autocratic leadership style is very important in obtaining efficient school financial management thus enabling 
teachers to plan and coordinate the financial management work given well and planned. Thus, a quality school was born in terms of financial management.

Financial management is also an important aspect of a business. According to Rameli et. al (2019), financial transactions should be done in an organized and effective manner to achieve the goals of a business's success. Without a good financial management system, not all business decisions can be made accurately because the decision-making process in a business is determined through information and financial data. This study shows the application of basic Islamic principles related to financial and business management. Among the principles are halal resources, how to obtain proper business capital, foundations, and rules as well as Islam on company spending and asset management. Therefore, Islamic financial management is inseparable from the concept of halal and awlawiyyat in procurement and expenditure.

However, financial management also faces obstacles and challenges to the application of accounting software in financial management especially school cooperative organizations. According to Hassan et. al (2018) school cooperatives in Malaysia use the accounting system SEKKOP123 however; its use has caused a failure in the system. This shows that the failure is due to several obstacles and challenges to the software. Among the aspects that have been identified are first the quality of the system, the quality of information, the quality of services, the less conducive environment, and individuals. Therefore, several methods have been done to overcome the challenge. These include maintenance services, continuous service, inservice training, and working with the parties involved. The results of the study can indirectly help school cooperatives and cooperatives in Malaysia in encouraging the application of accounting software systems in their organizations and their users.

Based on previous studies show studies on financial management from various angles involving individuals and organizations. However, the study of financial management in literary works does not show any study about it. Thus, the cluster of previous studies has led to a study on.

\section{Methodology}

According to Deacon and Firebaugh (1988) explain that family management is focused on financial factors and interrelated with economic factors. Money as one of the important resources of individual and family management is the focus of planning. Money plays several functions:

1. Be the basis of value comparison

2. Be a driver for change in the economic system

3. Can be used as a claim for future resource needs, and

4. As an intermediary to make exchanges and transfers with governments, institutions, private groups and individuals.

Money has a strategic function when families make decisions about their daily finances. An understanding of this function is important to answer some questions about the economic well-being of a family and the function of money in influencing goals and inspiration. In short, the principles of financial management are divided into three parts as in Figure 1 below: 


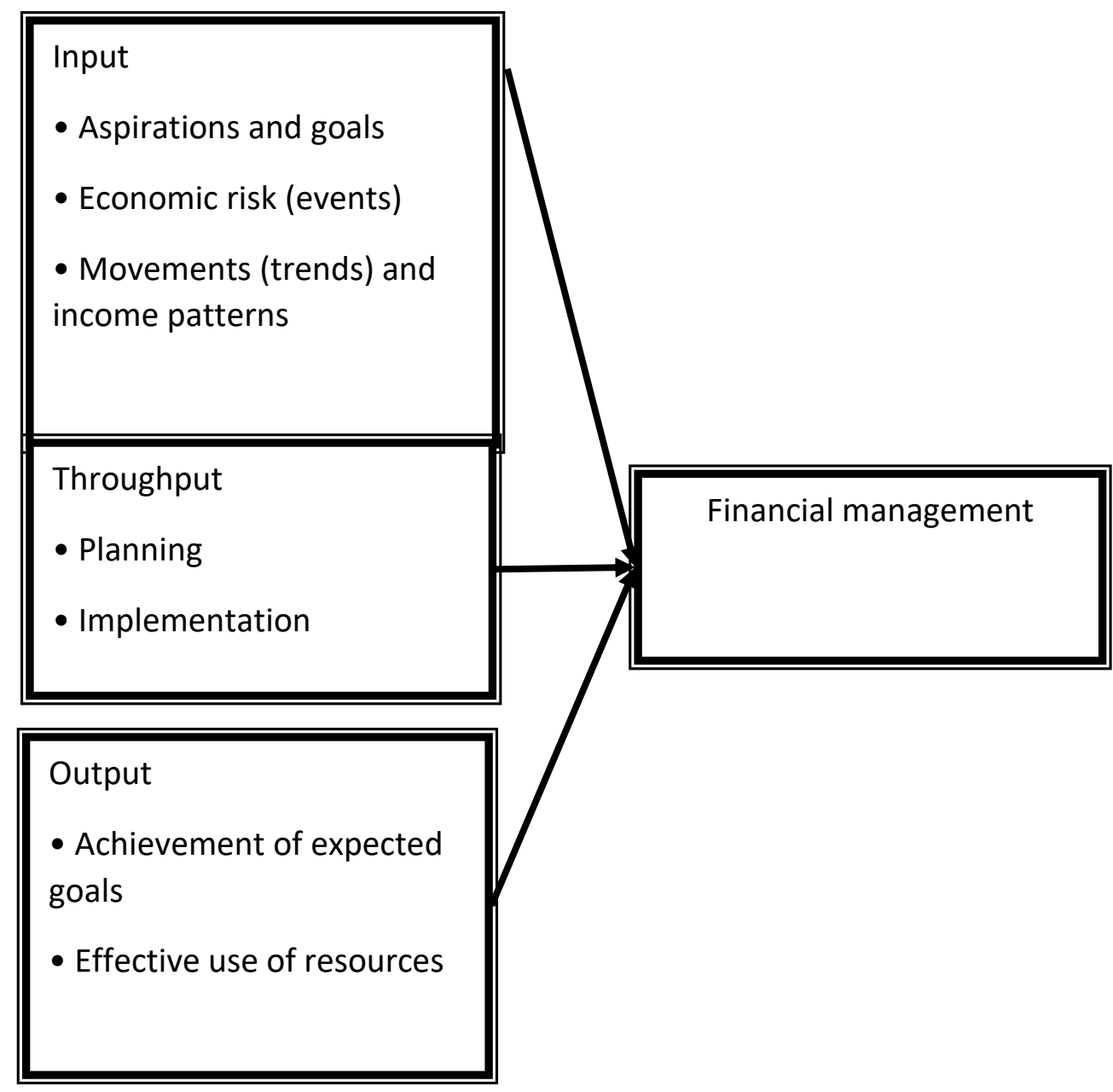

FIGURE 1. Principles of Financial Management

\section{Results}

This study was conducted using the principles of financial management as contained in the methodology section. Through this aspect will be conducted research on selected children's novels to prove that children's novels can not only provide entertainment but also educate readers to understand the field of financial management.

\section{Input}

The first principle that will be discussed in this study is related to input or understood as a source. According to Deacon and Firebaugh (1988: 52), the input is a source that is the source used to meet the needs or demands in a family system and can solve all manager problems. According to Othman (2002: 105), the input for the financial management system is related to goals, values, needs, and sources of income such as salaries, bonuses, dividends, and other sources. It is also stated that this input needs to be identified first to be able to plan and control expenses well. Goals should be ensured because this will be the main criteria in determining the trend of allocation of income sources that is from monthly or annual income. Sources from other sources also need to be identified to support goals and needs in financial planning. Therefore, it is understood that this input or resource is the main objective that must be owned first because this aspect will determine the direction of financial planning in a family. The strength of these resources will determine the style or way of life that a person 
will go through. With this new strength can be formed planning to determine financial aspirations and goals. Therefore, this section will explain the sub-topics contained:

\section{Aspirations and Goals}

The first is the sub-topics of aspirations and goals. According to Deacon and Firebaugh (1988: 123), every individual in a family has aspirations and goals that reflect the basic values of themselves. These aspirations and goals are associated with the needs and interests of each family member, namely the hopes and achievements related to the micro economy, economic conditions, uncertainty, opportunities and hopes to gain experience through interaction in the micro environment. It is stated that this feeling of satisfaction or economic well-being will be felt when aspirations are achieved and there are also opinions stating that this satisfaction is also felt regardless of the levels of resources available. However, it is known that this satisfaction will be reduced even if aspirations are achieved at low economic levels compared to satisfaction with aspirations achieved at high economic levels. Based on the opinion of many the difference between economic goals and achievement affects the level of economic well-being that is considered adequate by individuals and families. Thus, the goal is to imagine the real state of aspirations and expectations. If it is felt that more aspirations can be achieved then more aspirations adjustments must be made but if not many can be achieved will cause the opposite situation to happen.

Thus, there are five assessments used to create financial aspirations and goals. First is the complex interaction between the actual situation and the assessment that forms the financial goal, second is belief to meet basic needs is relative, third is a family living environment, fourth is a career in management to produce a positive perspective on the goal relationship with resources at all income levels. This is also influenced by age and value orientation factors. The fifth is the standard of education, which is a way to reduce the difference between the current and future levels of aspiration. According to Othman (2002: 33), goals are value-based objectives. The goal is to give direction or purpose to the values held. However, goals are more specific than values because goals can be fully achieved and their achievement requires continuous effort. Also stated are the goals formed through the will, philosophy of life, values, attitudes, and reactions from the environment, experiences, knowledge, and new information. Accordingly, this novel Iqbal Membina Jaya shows the goals and aspirations created through the character of lqbal while performing his financial management:

After everything was done, Iqbal continued his dream to collect aluminium cans. With the result of his collection, then he can save a lot. Do not expect the pocket money of the mother for more. Hopefully, his ambitions will be achieved. Apart from that, the desire to buy a Transformer Robot was so deep in his heart but his mouth did not reach to express it to his mother. (Bolhassan, 2015: 30)

Setelah semuanya selesai lqbal terus menyambung angan-angannya untuk mengutip tin aluminium. Dengan hasil kutipan beliau tersebut maka bolehlah beliau menabung dengan banyak. Tidak mengharapkan duit saku yang emak bagi lagi. Diharap cita-citanya akan tercapai. Selain itu hasrat untuk membeli Robot Transformer begitu menebal di lubuk hati tetapi mulutnya tidak kesampaian untuk menyatakannya kepada emak.

(Bolhassan, 2015: 30) 
Through the dialogue above, Iqbal's character has set his goal of collecting his financial resources by doing the job of collecting aluminium cans to achieve his goal of buying a Transformer game robot. This was also inspired when lqbal's character is said to have met a man who was collecting aluminium cans in his village to earn money and thus he immediately aspired to also perform the job to raise money. Through this, it can show the aspirations and goals of the character, lqbal, who aspires to save and raise money to buy his dream toy is finally achieved with hard work.

\section{Economic Risk (Events)}

Next, is the economic risk (events). According to Deacon and Firebaugh (1988: 125), these economic risks are caused by uncertainty over future events that make it difficult for a person to obtain a realistic relationship or consideration between financial goals and necessary resources. Based on the economic field of the family this risk is divided into two forms namely general economic risk and individual economic risk. This general economic risk can be defined as an economy beyond the power of the individual i.e. risks that will cause adverse conditions such as price changes, interest rates, and unemployment. While the individual economic risk is the situation or hardship of events experienced by an individual and this is not related to the current economic situation.

This individual economic risk due to the individual himself will be weak to face an event that has a great influence on resources. These economic risks refer to property loss, expenses for disability and medical, early retirement, and death. Economic risks caused by nonmonetary events and demands such as time, energy, attention, and consideration for an emergency can be reduced through financial management. This non-monetary demand can also be met by involving wider management and private subsystem. The function of part of financial management is to improve the financial stability of individuals and families and to be able to use that information to transfer financial risk from events to other predictable possibilities. The ability to cope with these emergencies also determines the level of consumption that can be maintained and profits made. The choice of resources that can be used as a variable is very important for economic stability. Accordingly, this novel lqbal Membina Jaya also shows that there are general economic risks that the character has to face to plan financial management:

"Now I take RM 2.80 but because your son is diligent I take it for RM 3.00 per kilo," Kader said as he opened his wallet. "If there are more cans, bring them here. Uncle sells at market price. Sometimes RM 2.00 per kilo. (Bolhassan, 2015: 147)

"Sekarang aku ambil memang RM 2.80 tetapi oleh kerana anak kau ini rajin aku ambil dengan harga RM 3.00 perkilo." Ujar Kader sambil membuka dompetnya. "kalau ada tin lagi, bawa sini. Pak cik jual ikut harga pasaran. Kekadang RM 2.00 sekilo (Bolhassan, 2015: 147)

Through the above quotation shows Iqbal's character also faces general economic risk when he cannot control the market price when intending to sell his proceeds. Buyers or buyers of shabby goods had to buy lqbal aluminum cans according to the market price but at that time the character gained profit through the rising market price and caused him to earn a lucrative income while selling his work. Thus, this matter clearly shows that lqbal's character has to face the general economic risk situation that is beyond his control, which is the market 
price for aluminum cans, and this will result in profit and loss that he will receive. Meanwhile, you can also see the economic risk of the individual that Iqbal's character had to face when he had to pay for the treatment of his sick pet cat and help pay his brother's fine. This somewhat disturbed the original planning done by lqbal's character so that he had to sell his aluminum cans earlier. But luck was still in his favour even though he had to take risks beyond his expectations.

\section{Movements (Trends) and Income Patterns}

Next, movements (trends) and patterns of opinion. According to Deacon and Firebaugh (1988: 126), most family financial resources are obtained through wages. There are differences in the characteristics of low-income groups and high-income groups. This comparison is seen with 20 percent of high-income families and 20 percent of low-income families that are lowincome families have young and old family heads, skin color, women, small family size, fewer family members working, more family members working in the services and operational sectors, fewer family heads working full time and less education. Meanwhile, high-income families have family heads who work full time and have other sources of income. Two-thirds of them are self-employed managers and professionals as well as the most highly educated.

Therefore, the financial position of the family is not affected by the inherited property but the rich family is likely to inherit most of the property compared to other families. This type of investment is also very important for many rich families, namely stocks, state and local bonds that are duty-free, and real estate. Besides, employment patterns and income diversification throughout the working cycle. When income starts to decrease and income capacity and varies according to employment i.e. low-paying jobs reach peak income faster compared to high-income jobs. Families ignore these differences when they first set their life goals.

Thus, gender factors also affect the family income pattern, and usually, the income of working women is also often uniform and does not show one round and this pattern will change as more women work throughout their life cycle. Income also depends on lessons, experience, and other factors and this pattern provides the basis for planning. Each family may have to adjust to the situation when the husband or wife goes on to get a job with the expected income and choose another more appropriate lifestyle. However, some of the methods used are not realized and it has helped more formal planning activities. It also acts to accelerate the use of resources to achieve the desired results. In this regard, the novel Iqbal Membina Jaya shows that movements (trends) and income patterns also influence Iqbal's character in his financial planning. This can be understood through the passage below:

\footnotetext{
"How many gathers?" Iqbal asked again wanting certainty.

"Collect a lot. When there are many new sellers. Gather until it is full, a lot of money".

"Can I keep it for a long time?"

"Yes."

"Uncle get a lot of money?" Iqbal continued to want to know.

"Can pay school fees as well. If we are diligent then we can get more,"

"How many cans, uncle?"

"People drink every day. Sometimes uncle takes it in the trash. The banks of this kind of river are also many. (Bolhassan, 2015: 23 - 24)
} 


\author{
"kumpul banyak mana?" Tanya lqbal lagi ingin kepastian. \\ "kumpul banyak-banyak. Bila sudah banyak baru jual. Kumpul sampai berguni, duit \\ pun banyak". \\ "boleh simpan lama-lama?" \\ "boleh." \\ "pakcik banyak dapat duit?" Iqbal terus mahu tahu. \\ "boleh bayar yuran anak sekolah juga. Kalau kita rajin maka lebih banyak lagi kita \\ dapat," \\ "banyakkah tin, pakcik?" \\ "orang minum setiap hari. Kadang-kadang pakcik ambil dalam tong sampah. Tepi \\ sungai macam ini pun banyak. (Bolhassan, 2015: 23 -24)
}

Through the above quotation, it can be understood that the income pattern of Iqbal character is determined through the collection of aluminum cans and this depends on the market price when the cans are successfully collected for sale. This makes the income flow rate of Iqbal's character can be said to be volatile and depends on the efforts made to collect the goods. Also, the location of the search influences the results obtained because aluminum cans are found in public areas and garbage disposal areas but he is a child causing himself to face obstacles. Indirectly, this also affects the income pattern of Iqbal's character.

\title{
Throughput
}

The basic functions of management remain the same although management goals, resources and actions vary according to individual problems as well as family organizational patterns and income flow conditions affecting planning and implementation.

\section{Planning}

Next, is the planning. According to Deacon and Firebaugh (1988: 129), the function of planning and implementation in management is to convert individual aspirations and resources into spending and savings patterns. Each individual or family converts their aspirations and values into goals or expectations related to the desired way of life. The first thing seen in planning is the budget. Budget in financial management is a plan made either mentally or verbally, generally or specifically. It shows how quantity or quality and when to distribute the available financial resources to various needs and wants. Budgets are very useful at times of transition and other times to control the financial situation. Budgets are not necessarily prepared in detail and complete but by identifying the expected resources at a time and the amount that needs to be distributed.

A budget is generally the beginning of a plan to identify the inputs that will be given major attention when creating a budget. According to him, the expenses of a family are different from other families due to differences in resources, values, and circumstances but the budget that has been prepared by other families can be used as a comparison. It is known that expenses for living stages vary by place. In this regard, the novel lqbal Membina Jaya shows the character of Iqbal also doing a budget to manage the money that he will earn as a result of his efforts:

"If Iqbal sells now, then he can get RM42.00. That's enough." Atuk Imam Shahdan gave hope. 
"What does lqbal want to do with the money later?" Atuk Imam Shahdan deliberately wanted to know.

"Iqbal wants to buy a transformer robot. The price is quite large RM28.90 but the cheapest. If it is bigger, the price is more expensive but lqbal only wants one. Friends are there but lqbal is not there.

"If you buy something cheap, there is more left. So Iqbal wants to make more money?" about Imam Shahdan again.

"Iqbal wants to save, Grandpa."(Bolhassan, 2015: 112 - 113)

"Kalau Iqbal jual sekarang maka boleh dapat RM42.00. Lumayan tu." Atuk Imam Shahdan memberi harapan.

"Iqbal nak buat apa dengan duit itu nanti?" Atuk Imam Shahdan sengaja ingin tahu. "Iqbal nak beli robot transformer. Harganya yang agak besar RM28.90 tapi yang paling murah. Kalau yang besar lagi harganya lebih mahal tapi lqbal hanya nak satu. Kawan-kawan ada tapi lqbal tak ada.

"Kalau beli yang murah ada bakinya lagi. Jadi lqbal nak buat apa duit lebihnya?" soal Atuk Imam Shahdan lagi.

"lqbal nak menabung, Atuk." (Bolhassan, 2015: 112 - 113)

Through the passage above shows the character lqbal has made plans in managing his finances. He stated that once he has earned the proceeds from the sale of aluminum cans, he will give cheaper toy robots and the rest will be kept in coffers for future expenses. The character has made a budget to achieve something desired as well as trying to raise money to guarantee his life in the future.

\section{Implementation}

Next, is the implementation. According to Deacon and Firebaugh (1988: 141), implementation is part of financial management that is testing the situation that has been planned to see the action when the situation occurs. As is well-known budgets are used to control future expenses and this is seen from the aspect of the use of records and organizational patterns. Referring to the use of this record is to make a comparison between actual expenses and budgets. A family needs to record the needs that must be possessed and need to be balanced with the source of income.

Thus, spending that is close to the target or budget will usually not affect management but if there is a big difference then the financial restructuring needs to be changed again. In this regard, the implementation will also focus on organizational patterns that carry the meaning of existing patterns or plans facilitate financial planning and implementation by specifying roles or arrangements. It is stated usually in a family wife or husband will not be in financial management simultaneously but must be determined according to the abilities of the individual. This matter can also not be determined according to the traditional role that shows the husband will manage every big purchase but in fact, a person's success in carrying out responsibilities depends on interest, experience, and work schedule. In this regard, the novel lqbal Membina Jaya also shows the character lqbal has implemented in his financial management: 
"All lqbal money is RM106.30, right?

"Yes. Includes tube money. Everything is with mom."

"Let's go see a vet. (Bolhassan, 2015: 148)

When it was all over, lqbal and his mother went back to the counter to take medicine and pay for medicine and services. How relieved my mother was when the payment was only RM30.00.(Bolhassan, 2015: 152)

"Let lqbal pay the price of my brother's textbook." Mom immediately looked at Iqbal's face.

"Iqbal's money is still there. Use lqbal money."

"Iqbal wants to buy a transformer robot."

"It's okay, still enough. Iqbal can buy another robot for RM28.90. " (Bolhassan, 2015: 156)

"Semua duit lqbal RM106.30, kan?

"Ya. Termasuk duit tabung. Semua ada dengan mak."

"Jom kita pergi jumpa doktor haiwan." (Bolhassan, 2015: 148)

Apabila selesai semuanya lqbal dan mak pun pergi semula ke kaunter untuk mengambil ubat dan membayar ubat dan perkhidmatan. Alangkah leganya hati mak apabila bayarannya cuma RM30.00.(Bolhassan, 2015: 152)

\footnotetext{
"Biar lqbal yang bayar harga buku teks abang". Mak segera memandang wajah lqbal.

"Duit lqbal kan masih ada. Guna duit Iqbal."

"Kan Iqbal nak beli robot transformer."

"Tak apa, masih cukup. Iqbal boleh beli lagi robot yang harga RM28.90 tu."

(Bolhassan, 2015: 156)
}

Through the entire passage above shows the implementation done by the character lqbal when he had to change his financial expenses because he was faced with unforeseen circumstances such as having to pay the cost of pet cat care and the amount of fine his brother lost the textbook. Although there are differences between the budgets that lqbal has made he still managed to fulfil his dream of buying a transformer toy robot.

\section{Output}

\section{Achievement of Expected Goals}

Next, is the achievement of the desired goal. According to Deacon and Firebaugh (1988: 143), the expected result in financial management is to meet demand and focus on the most effective way of spending money. In terms of demand, measured results are expected to provide satisfaction and achievement with decisions and actions performed using the money allocated. Therefore, each of these things needs to be evaluated to see that the decisions taken are accurate or need to be modified. 
If my mother knew that the payment was only RM 30.00, maybe she would bring Comot earlier but this is the first experience of bringing an animal to see a veterinarian.

"Pity lqbal. You have to pay for it yourself." Said mak as they both drove towards the car.

"It's okay mom, use Iqbal's money. That's the intention. "Iqbal said.

After this, Iqbal can buy a slightly expensive Transformer. (Bolhassan, 2015: 151 152)

Kalaulah mak tahu bayarannya hanya RM 30.00 mungkin dia akan membawa Comot dengan lebih awal tetapi ini pengalaman pertama membawa seekor binatang berjumpa doktor haiwan.

"kasihan lqbal. Kena bayar sendiri." Omel mak semasa mereka berdua beriring menuju ke kereta.

"tak apalah mak, guna duit lqbal tu. Kan sudah niat." Ujar lqbal.

Selepas ini bolehlah lqbal beli Transformer yang mahal sikit. (Bolhassan, 2015: 151

-152)

Through the above quotation, it can be seen that Iqbal's character is satisfied with the achievements made when he not only managed to achieve his ambitions but also rejoiced when he also managed to fulfil his desire to treat his pet cat with his own money. All the achievements gained through his hard work made him more confident to continue to fight to collect aluminum cans again. His dream of having a Transformer robot can also be realized using his sweat points.

\section{Effective Use of Resources}

Next is the effective use of resources. According to Deacon and Firebaugh (1988: 144), the effective use of resources is divided into two, namely human capital and net worth. This human capital refers to one's ability to perform family financial management after going through the experience and identifying financial issues that can be handled as best as possible. As such, human capital such as education and health also influences the potential to contribute to individual production and family income. Meanwhile, the net value is the balance between property and liabilities that is constantly changing but if this net value is not balanced, it will have a bad effect like bankruptcy. Thus, the balancing influence that is property, repayment period, and financial condition must be observed.

lqbal is happy because all his family members have cooperated in his previous efforts. Anyone who finds an aluminium can be taken home and will be put in a sack. lqwan is no exception but he is determined that if they sell him later his share will be used to pay his debt to Iqbal. (Bolhassan, 2015: 159 - 160)

Iqbal gembira kerana seluruh ahli keluarganya memberi kerjasama dalam usahanya sebelum ini. Siapa sahaja yang terjumpa tin aluminium akan dibawa pulang dan akan dimasukkan ke dalam guni. Iqwan juga tidak terkecuali malah dia bertekad kalaulah mereka menjualnya nanti bahagiannya akan digunakan untuk membayar hutangnya kepada lqbal. (Bolhassan, 2015: 159 - 160) 
Through the quotation above, it can be seen that the success made by the character Iqbal not only achieved his ambition to own the game but also changed the stance of his entire family members to be together in collecting aluminum cans. The perseverance shown by lqbal has a positive effect when his family can find new ways to deal with the family economic crisis by collecting aluminium cans so that they can be sold when necessary.

\section{Conclusion and Recommendations}

After this research is implemented, it can be seen that the novel Iqbal Membina Jaya by Radzemah Bolhassan indeed has an aspect of family financial management that can provide education or added value to readers, especially children. The author of a children's novel can meet this element of financial management organized by Deacon and Firebaugh. Aspects of input, throughput, and output in financial management are seen to be successfully applied by the author in the novel by using a simple understanding and appropriate to the thinking of the reader's children. Children will indirectly know the needs in managing their finances that is first needed to build capabilities in finance which in turn can help to cover daily expenses as well as fulfil desires such as buying toys and reading materials. Therefore, the conflict highlighted by the author on this financial problem will open the minds of children to always be sensitive and ready to face the crisis.

Therefore, this study has opened space and opportunities for financial management knowledge in family institutions to educate family members, especially parents and children in managing finances well to be harmony and well-being in family institutions. Researchers also hope that this study can provide an overview to future researchers to develop this study by involving the study of questionnaires and respondents as well as the study by analyzing the content of the text.

\section{Corresponding Author}

Mohd Shukrey Ahmad

Faculty Modern Language and Communication, Universiti Putra Malaysia, Serdang, Selangor, Malaysia.

Email: mshukreyahmad@gmail.com

\section{References}

Ahmad, A., Omar, K. (1988). Ekonomi rumahtangga. Petaling Jaya: Longman Malaysia Sdn. Bhd.

Arus, I. K. M., Samsuddin, S., Zawawi, N. H., \& Ghani, M. F. A. (2018). Kepimpinan Guru Besar dan keberkesanan pengurusan kewangan peruntukan geran perkapita Sekolah Rendah Zon Bangsar. Jurnal Kepimpinan Pendidikan. 5(2), 26-44.

Azmi, S. N. S., Rahman, S. A., Ibrahim, S., Muhammad, N., \& Esa, M. M. (2018). Amalan pengurusan kewangan mahasiswa. Journal of Business Innovation. 3(2), 9-23.

Bolhassan, R. (2015). Iqbal Membina Jaya. Kuala Lumpur: Dewan Bahasa dan Pustaka.

Deacon, R. E., Firebaugh, F. M. (1988). Pengurusan sumber keluarga prinsip dan aplikasi. (Trans.) Yahaya, N. \& Othman, M. Serdang: Penerbit Universiti Putra Malaysia.

Halim, Z. A. (2015). Kepentingan dan peringkat awal perancangan kewangan. Utusan Online. Retrieved from http://www.utusan.com.my/bisnes/ekonomi/kepentingan-danperingkat-awal-perancangan-kewangan-1.32672 
Hassan, H. A., Aman, A., Aziz, K. A. \& Senin, S. (2018). Cabaran aplikasi perisian perakaunan dalam pengurusan kewangan koperasi sekolah. Asian Journal of Accounting and Governance. 10, 145-160. http://dx.doi.org/10.17576/AJAG-2018-10-13

Kenayathulla, H. B., Subramaniam, R., \& Ghani, M. F. A. (2015). Pengurusan kewangan di Sekolah Jenis Kebangsaan Tamil di Kuala Kangsar, Perak: Satu kajian kes. Jurnal Kepimpinan Pendidikan. 1(4), 62-82.

Khan, F. F. F. (2015). Subur cilik tabiat menabung. MyMetro. Retrieved from https://www.hmetro.com.my/node/39250

Norazam, N. S., Othman, N., (2017). Kualiti pendidikan pengurusan kewangan dengan tahap literasi kewangan. Journal of Global Business and Social Entreneurship. 1(1), 183-193.

Othman, M. (2002). Pengenalan pengurusan sumber individu dan isi rumah pendekatan sistem. Serdang: Penerbit Universiti Putra Malaysia.

Rahman, A. R., Zulkifly, W. (2016). Faktor penentu pengurusan kewangan: Kes mahasiswa Universiti Kebangsaan Malaysia. Jurnal Personalia Pelajar. 19(2), 85-94.

Rahman, M. Y. M. (2014). Pupuk tabiat kewangan anak-anak. Ringgit. 11(14), 2-3 Retrieved from https://www.bnm.gov.my/documents/20124///83f4e6b5-663d-5be2-1d929bc55e881533

Rahman, N. S. A., Muhammad, S. J. N., Sujud, A., (2019). The management of emotional problem in Malay hikayat using Islamic method. In. Habidin, N. F., et. al. Emerging Trends and Challenges in Management: Strategy, Practices and Performance Measurements. Tanjong Malim: Kaizentrenovation Sdn. Bhd.

Rameli, M. F., Amin, S. M., Man, N. C., Aris. N. M., Wahab, N. A. A. (2019). Pengurusan kewangan Islam dalam kalangan muslimpreneurs menurut perspektif ilmuwan Islam di Malaysia. Online Journal of Research in Islamic Studies, 6(Special Issue), 79-85.

Ramli, Z., Farid, N. A. M., Sum, S. M., \& Manaf, A. A. (2020). Strategi pengurusan kewangan mahasiswa berkahwin: Kajian perbandingan Malaysia dan Indonesia. Journal of Social Sciences and Humanities. 17(4), 90-104.

Sabri, M. F., Dass, T. M, Lee, M. P., Zakaria, N. L., Wahab, R. \& Ramli, N. N. (2017). Does The Bijak Wang (Smart Money) programme benefit school going children? Malaysian Journal of Consumer and Family Economics. 20(S2), 123-143.

Samah, R. (2017). Masalah kewangan punca perceraian. Utusan Online. Retrieved from http://www.utusan.com.my/rencana/forum/masalah-kewangan-8232-puncaperceraian-1.538780 